mgr inż. Marcin Barański

dr inz. Adam Decner

mgr inz. Tomasz Jarek

dr in.. Artur Polak

Instytut Napędów i Maszyn Elektrycznych KOMEL

\title{
Autonomous, telemetric, multi-channel system of data acquisition to monitor the traction electric machines
}

\begin{abstract}
The structure of the measurement system based on the cellular networks is relatively easy and cheap in building and operation. Remote monitoring system must be appropriately adapted to the specific requirements of network, it is necessary the appropriate equipment allowing to record and transmit the data on the GSM network or the Internet. Operation of the device is presented in this article on the basis of an interesting case of damage of the traction electric motors. The motors were used for driving of vehicles, and the measurements were made during the normal vehicle operation. The examples of measurement results are also presented. Measurements and recordings were carried out remotely using the telemetric devices, whose concept was developed by the authors of this article. Structure of the autonomous, telemetric, multi-channel system and the possible applications are also presented. The authors plan to expand the capabilities of the device by the measurement of other non-electrical quantities.
\end{abstract}

\section{Autonomiczny, telemetryczny, wielokanałowy system akwizycji danych do monitorowania trakcyjnych maszyn elektrycznych}

\begin{abstract}
Budowa systemu pomiarowego opartego o sieci komórkowe jest stosunkowo łatwa i tania $w$ budowie $i$ eksploatacji. System zdalnego monitoringu musi zostać odpowiednio dostosowany specyficznych wymagań sieci, niezbędne jest odpowiednie wyposażenie, umożliwiajace rejestrowanie i przesyłanie danych w sieci GSM lub Internet. Działanie urzqdzenia zostato przedstawione $w$ artykule na podstawie ciekawego przypadku uszkodzeń trakcyjnych silników elektrycznych. Silniki byty wykorzystywane do napędu pojazdów szynowych a pomiary zostaly wykonane $w$ trakcie normalnej eksploatacji pojazdu. Przedstawiono również przykładowe wyniki pomiarów. Pomiary i rejestracje wykonywane byly zdalnie za pomocq urzqdzeń telemetrycznych, których koncepcja została opracowana przez autorów niniejszego artykutu. Budowa autonomicznego, telemetrycznego, wielokanałowego systemu oraz możliwe zastosowania również zostały przedstawiane. Autorzy planuja poszerzenie możliwości urzadzenia o pomiar innych wielkości nieelektrycznych.
\end{abstract}

\section{WSTEPP}

Maszyny elektryczne, jak każde urządzenie elektryczne czy mechaniczne ulegają awariom. Duży wpływ na awaryjność ma charakter pracy oraz warunki pracy. Zużywanie się podzespołów maszyny oraz ich niewłaściwa eksploatacja są przyczynami większości awarii. Wykluczając niewłaściwą eksploatację i analizując przyczyny pozostałych awarii, można stwierdzić, że są one konsekwencją postępujących procesów starzenia oraz zużywania się materiałów zastosowanych do wytworzenia danej maszyny.

Zdaniem autorów ocena stanu technicznego maszyn elektrycznych często jest błędna. Przykładem może być diagnostyka stanu technicznego klatek wirników silników indukcyjnych. Silnik indukcyjny z uszkozoną klatką może pracować na pozór normalnie, może

\section{INTRODUCTION}

Electric machines, like any electrical or mechanical device have failures. The nature of work and working conditions have the high impact on the failure frequency. Wear of the subassemblies of the machine and the wrong operation are the causes of most failures. Excluding the wrong operation and analyzing the causes of other failures, it can be found that they are a consequence of the progressive ageing processes and wear of the materials used in the production of the machine.

According to the authors the assessment of the technical condition of electric machines is often wrong. The diagnosis of technical condition of cages of induction motors rotors can be an example. The induction motor with damaged cage can work 
nawet dokonywać kolejnych rozruchów, a początkowe, drobne pęknięcie jednego pręta są początkiem procesu niszczenia klatki, który to proces ma charakter postępujący i w konsekwencji prowadzi do poważnej awarii silnika $\mathrm{z}$ awarią katastrofalną włącznie [5], [9], [11], [12], [13-16]. Autorzy w czasie prowadzenia badań diagnostycznych w zakładach reprezentujących różne gałęzie przemysłu spotykali się $\mathrm{z}$ trzema typami nadzoru nad pracującymi urządzeniami:

1. Ciagły monitoring, diagnostyka w systemie (online) połączony z bieżącym śledzeniem jej parametrów ruchowych pozwala określać stan techniczny maszyny i zaawansowanie procesów starzenia. Przyjmując odpowiednie kryteria istnieje możliwość generowania alarmów o różnej wadze.

2. Okresowa diagnostyka off-line maszyn elektrycznych pozwala na wyznaczenie tendencji i szybkości zachodzących zmian niektórych parametrów określających stan techniczny maszyny.

3. Diagnostyka off-line wykonywaną jedynie w przypadku zauważenia przez służby utrzymania ruchu/obsługę niepokojących symptomów, którymi mogą być: pojawienie się dymu, zadziałanie czujników ochrony termicznej, subiektywny wzrost hałasu pracującego urządzenia itp. Pojedyncze testy diagnostyczne dostarczają informacji o aktualnym stanie technicznym maszyny elektrycznej.

\section{AUTONOMICZNY, TELEMETRYCZNY, WIELOKANALOWY SYSTEM AKWI- ZYCJI DANYCH}

Wieloletnie doświadczenia autorów w dziedzinie badania, diagnostyki i monitoringu maszyn elektrycznych pozwoliły na opracowanie urządzenia, które jest wykorzystywane podczas pomiarów prowadzonych głównie w warunkach przemysłowych. Urządzeniem tym jest telemetryczny, wielokanałowy system akwizycji danych umożliwiający monitorowanie pracy maszyn i urządzeń elektrycznych. Urządzenie to zaprojektowane przez autorów może pracować w niekorzystnych warunkach środowiskowych: bardzo duży hałas i wibracje, zapylenie, oddziaływanie warunków atmosferycznych itp.

Prezentowany telemetryczny, wielokanałowy system akwizycji danych (rys. 1) posiada funkcje pozwalające na wykonanie rejestracji, pomiaru, zapisanie wyników oraz przesłanie informacji o aktualnej sytuacji związanej z obiektem badań. Oprogramowanie urządzenia pozwala na rejestracje wartości chwilowych, średnich oraz skutecznych mierzonych sygnałów oraz definiowanie wartości progowych, które wyzwalają rejestrację zadeklarowanych wielkości. Dla każdego kanału próg zadziałania może być nasta- seemingly normal, it can even make the next starts, and the initial, small crack of one of the rod is the beginning of the process of destruction of the cage. The process is progressive and leads to serious motor failure with the catastrophic failure, including [5], [9], [11], [12], [13-16].

The authors during carrying out the diagnostic tests in plants representing the various industries met with three types of supervision of working devices:

1. Continuous monitoring, diagnosis in the system (on-line) connected to the current tracking of its movement parameters makes it is possible to determine the technical condition of the machine and the advancement of the ageing process. Assuming the relevant criteria it is possible to generate the alarms with different size.

2. Periodic off-line diagnosis of electric machines allows to determine the trends and rates of changes of some parameters that define the technical condition of the machine.

3. Off-line diagnosis performed only when worrying symptoms are seen by the maintenance service/support service, to which it may be included: the appearance of smoke, the triggered sensors of thermal protection, the subjective increase of noise of working device etc. The individual diagnostic tests provide information about the current technical condition of the electric machine.

\section{AUTONOMOUS, TELEMETRIC, MULTI -CHANNEL SYSTEM OF DATA ACQU- ISITION}

Many years of experience of the authors in the field of tests, diagnosis and monitoring of electrical machines allowed to develop a device which is used during measurements mainly carrying out in the industrial conditions. This device is telemetric, multi-channel system of data acquisition enabling to monitor the operation of machines and electrical equipment. This device designed by the authors can work in adverse environmental conditions: very large noise and vibrations, dust emissions, effect of atmospheric conditions, etc.

The presented telemetric, multi-channel system of data acquisition (Fig. 1) has the functions to perform the recording, measurement, the results recording and sending the information about the current situation connected with the object of study. The device software allows to record the instantaneous values, the average and effective measured signals and to define the threshold values that trigger recording of the declared quantities. For each channel, the threshold value can be set independently. The request to generate a report of performed recordings on the object and the device condition can be sent using the appropriately formatted SMS or e-mail. All these features give the user the possibility of remote 
wiany niezależnie. Żądanie wygenerowania raportu z wykonanych rejestracji na obiekcie jak i stanu urządzenia można przesłać za pomocą odpowiednio sformatowanej wiadomości SMS bądź e-mail. Wszystkie powyższe cechy dają użytkownikowi możliwości zdalnego kontrolowania urządzenia pomiarowego jak i procesu pomiarowego.

W celu przybliżenia zasady działania oraz części składowych urządzenia, na rysunku 2 przedstawiony jest schemat blokowy urządzenia rejestrującego. Sercem całego układu jest procesor sygnałowy (DSP). Jest to wyspecjalizowany układ do obróbki sygnałów cyfrowych. W jednym układzie zawarte sa:

- układ kontroli

- jednostka arytmetyczno-logiczna

- pamięć ROM i RAM

- układy wejściowe

- układy wyjściowe.

Przedstawiony na rys. 2 schemat blokowy urządzenia spełnia wszystkie założenia (dotyczące pomiarów i przetwarzania danych) wymienione powyżej.

Technologia GSM/GPRS jest doskonale dopasowana dla systemów monitoringu i telemetrii. Posiada wiele zalet, m.in.:

- dostępność komunikacji GSM,

- możliwość korzystania $\mathrm{z}$ istniejącej struktury sieci transmisyjnej,

- duży zasięg sieci,

- niskie koszty budowy i eksploatacji systemu,

- brak konieczności stosowania specjalnych anten,

- koszt utrzymania struktury umożliwiającej transmisję przeniesiony na operatora,

- opłata za rzeczywistą ilość przesłanych danych. Aby funkcja zdalnego monitoringu funkcjonowała poprawnie, konieczne jest umieszczenie w urządzeniu odpowiednio skonfigurowanej karty SIM operatora GSM, oferującego usługi $\mathrm{w}$ zakresie transmisji danych [10].

\section{ZASTOSOWANIE TELEMETRYCZNE- GO, WIELOKANALOWEGO SYSTEMU AKWIZYCJI DANYCH W DIAGNOSTY- CE PRZEMYSLOWEJ}

Zalety opisanego urządzenia wykorzystano m.in. w poszukiwaniu przyczyn uszkadzania się wirników silników indukcyjnych klatkowych zastosowanych do napędu pojazdów trakcji kolejowej (rys. 3, 4).

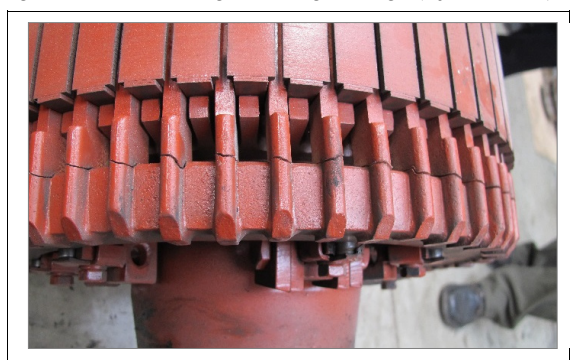

Rys. 3. Uszkodzone uzwojenie wirnika silnika trakcyjnego Fig. 3. Damaged rotor winding of traction motor controlling of the measuring device and the measuring process.

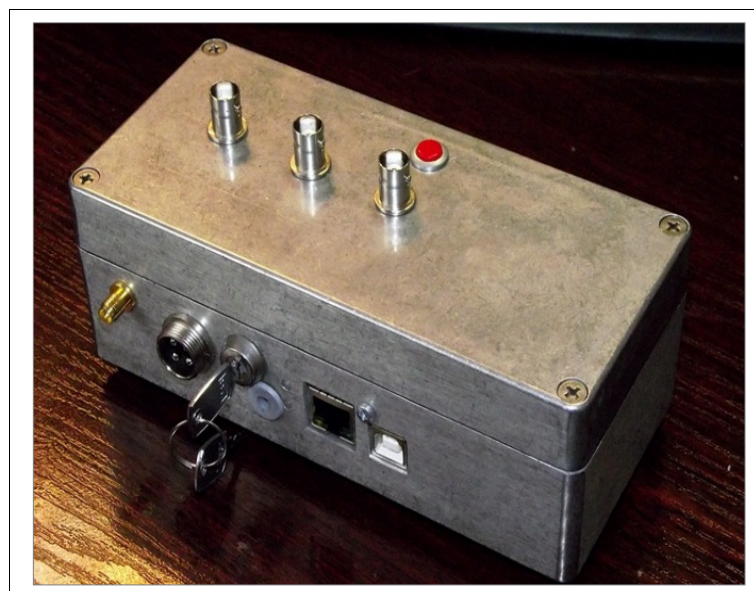

Rys. 1. System akwizycji danych w wykonaniu trójkanałowym

Fig. 1. The data acquisition system in a three-channel version

To introduce the operating principles and components of the device, a block diagram of the recording device is presented in Figure 2. The heart of the whole system is a digital signal processor (DSP). It is a specialized system for processing the digital signals. In one system it is included:

- control system

- arithmetic and logic unit

- ROM and RAM memory

- input systems

- output systems

The presented in Fig. 2 block diagram of the device meets all the assumptions (for the measurements and data processing) listed above.

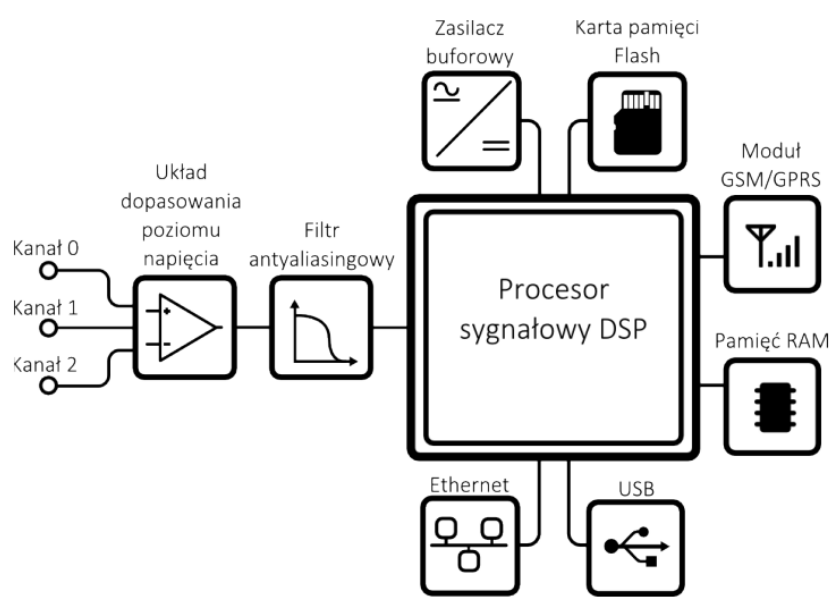

Rys. 2. Schemat blokowy wielokanałowego systemu akwizycji danych

Fig. 2 Block diagram of a multi-channel system of data acquisition

GSM/GPRS technology is well adjusted for systems of monitoring and telemetry. It has many advantages, inter alia:

- availability of GSM communication,

- possibility of using the existing structure of the transmission network, 


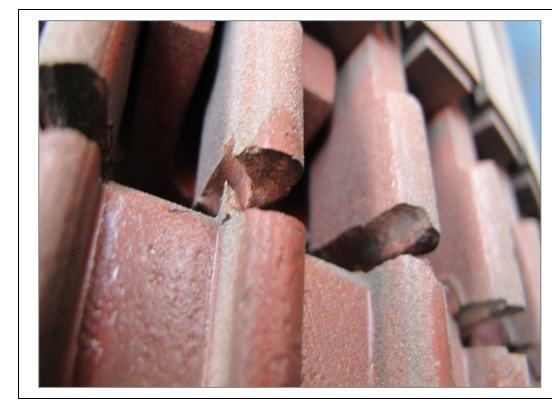

Rys. 4. Przełom uszkodzonych prętów wirnika silnika trakcyjnego

Fig. 4. Broken damaged rotor bars of traction motor

Wyniki przeprowadzanych wcześniej testów nie pozwalały na sformułowanie jednoznacznych wniosków. Taki stan był bezpośrednią przyczyną zaproszenia do badań zespołu badawczego złożonego $\mathrm{z}$ autorów niniejszej publikacji. Po zapoznaniu się ze skalą problemu, oraz przeanalizowaniu struktury zasilania i układu mechanicznego, skonfigurowano system pomiarowy przeznaczony do wykonania pomiarów na pojeździe trakcyjnym. System pomiarowy opierał się na wyselekcjonowaniu odpowiednich czujników, które umożliwią pomiar i rejestrację sygnałów o zmiennej częstotliwości i umożliwią niezawodną współpracę z układem telemetrycznym. Po zaprogramowaniu parametrów rejestracji (wartości progowe, sposób i czas archiwizacji) urządzenia zostały zamontowane w pojeździe trakcyjnym (rys. 5, 6).

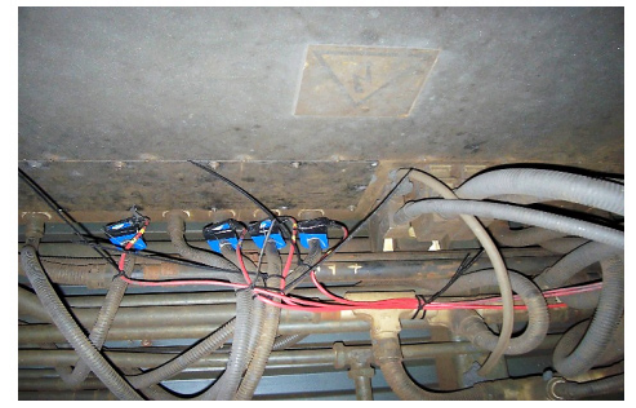

Rys. 5. Przetworniki prądu zamontowane pod pojazdem szynowym

Fig. 5. Current converters mounted under the rail vehicle

Badania były przeprowadzone zdalnie 30 dni normalnej eksploatacji pojazdu trakcyjnego. Rozpatrywane hipotezy przyczyn występowania awarii zostały ograniczone do jednej, głównej przyczyny: praca silników w warunkach występowanie częstotliwości zbliżonych do częstotliwości własnych wirników.

Na rysunku 7 przedstawiono wyniki rejestracji pradów tej samej fazy dwóch silników zasilanych z tego samego falownika napędzających ten sam zestaw napędowy. Wyniki rejestracji ujawniają różnice $\mathrm{w}$ obciążaniu się poszczególnych maszyn podczas przyspieszania i hamowania dynamicznego (odzyskowego). Rysunek 8 przedstawia zarejestrowane wszystkie prady jednego silnika oraz prąd jednej fazy silnika drugiego podczas hamowania dynamicznego podłączonych do tego samego falownika. Porównując
- large range of network,

- low costs of construction and operation of the system,

- no necessity to use the special antennas,

- cost of the structure maintenance for transmission transferred to the operator,

- fee for the actual amount of transferred data.

It is necessary to place in the device the properly configured SIM card of GSM operator offering the services in the field of data transmission [10] for correct functioning of remote monitoring function.

\section{APPLICATION OF TELEMETRIC, MUL-TI - CHANNEL SYSTEM OF DATA ACQ- UISITION IN INDUSTRIAL DIAGNOSIS}

The advantages of the described device were used, inter alia, in search of the causes of damage of the cage induction motors rotors used to drive the railway traction vehicles (Fig. 3, 4).

The results of the tests carried out previously did not allow to form the clear conclusions. This condition was the direct cause of the invitation the research team, consisted of the authors of this publication, to carry out the tests. After acquainting with the scale of problem and analyzing the structure of power and the mechanical system, the measuring system, designed to carry out the measurements on the traction vehicle, was configured. The measuring system was based on selecting the appropriate sensors that allow to measure and record the signals with the variable frequency and they enable the reliable cooperation with the telemetric system. After programming the recording of parameters (threshold values, method and time of archiving) the devices were mounted in the traction vehicle (Fig. 5, 6).

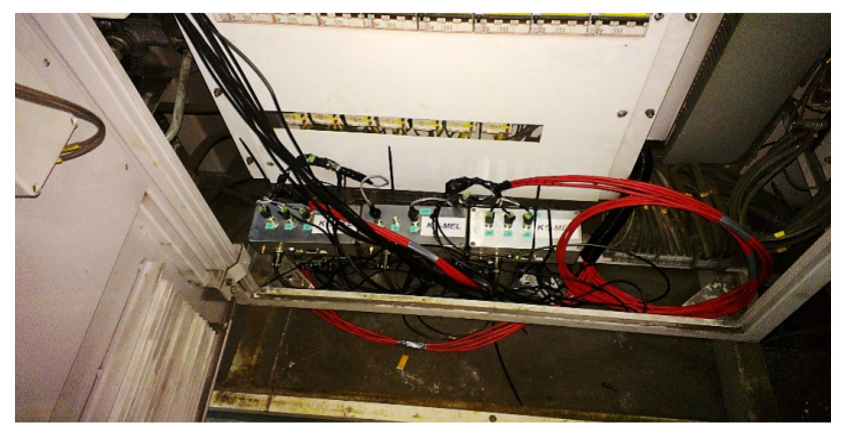

Rys.6. Wielokanałowy system akwizycji danych zamontowany w rozdzielni pojazdu szynowego

Fig. 6. Multi-channel system of data acquisition installed in the distribution board room of rail vehicle

The tests were carried out remotely for 30 days of the normal operation of the traction vehicle. The considered hypothesis of reasons of the failure occurring were limited to one main reason: the work of motors in conditions of frequency occurrence similar to the frequency of their rotors.

Figure 7 shows the results of recording the currents of the same phase of the two motors that are powered 
prądy fazowe obu silników można zaobserwować powstające asymetrie.

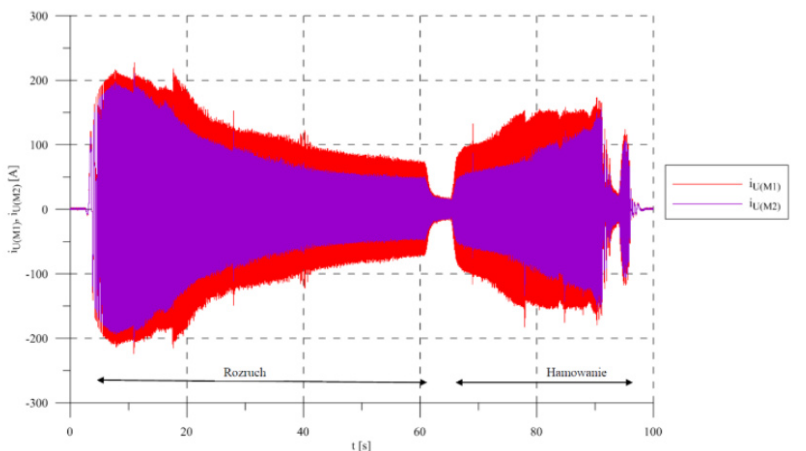

Rys. 7. Przebieg czasowy prądów silników podczas rozruchu oraz hamowania dynamicznego

Fig. 7. The time course of the motors currents during start-up and dynamic braking

Wykorzystanie telemetrycznego, wielokanałowego systemu akwizycji danych umożliwiło przeprowadzenie analizy drgań występujących na diagnozowanych silnikach. Rysunek 9 przedstawia fragment zarejestrowanego widma drgań z zaznaczonymi dominuącymi częstotliwościami.

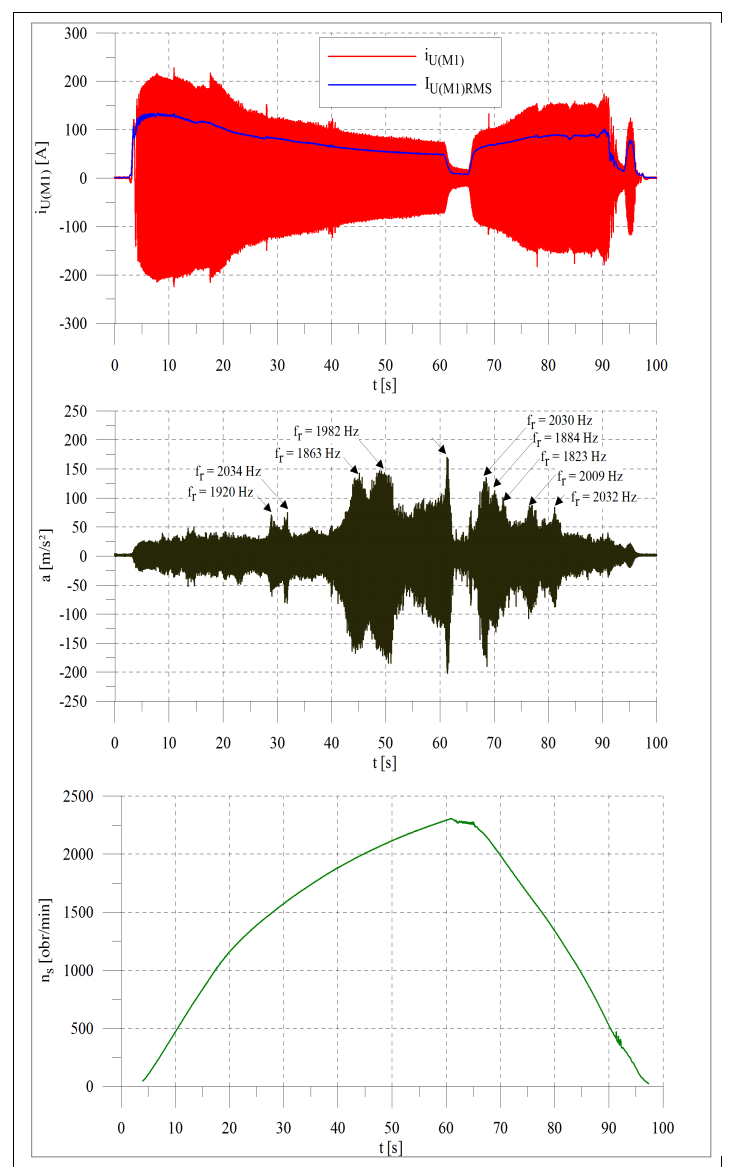

Rys. 9. Przebiegi czasowe podczas rozruchu oraz hamowania dynamicznego pojazdu szynowego: a)wartości chwilowe oraz skuteczne prądu silnika, b)wartości chwilowe przyspieszenia drgań, c)prędkości synchronicznej

Fig. 9. Time courses during start-up and dynamic braking of the rail vehicle: a) the instantaneous and effective values of engine current, $b$ ) the instantaneous values of the vibration acceleration, c) the synchronous speed from the same inverter driving the same drive set. The results of recording reveal the differences in loading of the individual machines during acceleration and dynamic braking (regenerative).

Figure 8 shows all recorded currents of one engine and the current of one phase of the second engine during the dynamic braking connected to the same inverter. Comparing the phase currents of both motors it can be observed the emerging asymmetries.

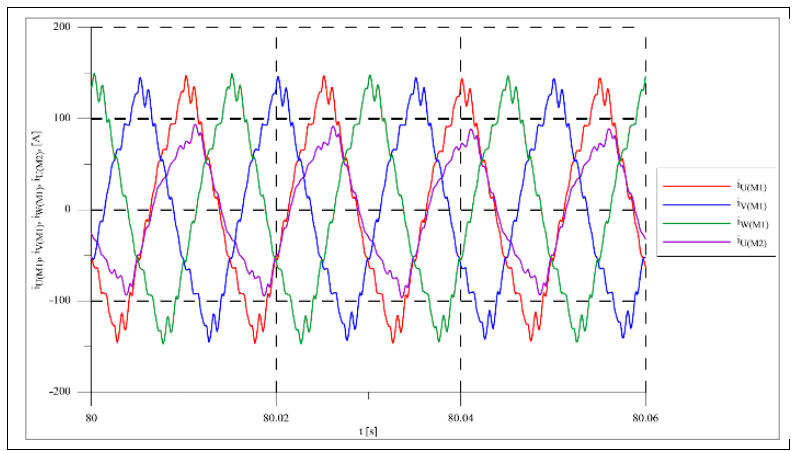

Rys. 8. Przebieg czasowy prądów silników podczas hamowania dynamicznego

Fig. 8. The time course of the motors currents during dynamic braking

The application of telemetric, multi-channel system of data acquisition enabled to carry out the analysis of vibration occurring on the diagnosed motors. Figure 9 shows a fragment of the recorded spectra of vibration with the emphasized dominant frequencies.

\section{CONCLUSIONS}

The presented in this article selected results are an example of a multi-plane approach to the problem of measurements of the electric machines in the industrial conditions. The standard measuring and recording equipment, which is used in the research laboratories, does not work during measurements carrying out on the objects working in the industrial devices. In such situations it is required the more creativity in the configuration of the measuring systems. Carrying out the long-term measurements often requires building own instruments, e.g. recorders, which is presented in the article. The usefulness of the presented solutions in engineering practice is confirmed by the obtained results.

At present the authors are working on using the telemetric, multi-channel system of data acquisition as a tool for vibration diagnosis without sensors of the electric machines induced by the permanent magnets [1-8]. It is a new diagnostic method intended for diagnostic monitoring for generators and moors with inducing from the permanent magnets.

\section{LITERATURA BIBLIOGRAPHY}

[1] Barański M., Vibration diagnostic method of permanent magnets generators - detecting of vibrations caused by unbalance. IEEEXplore, Ever, 2014 


\section{WNIOSKI}

Prezentowane w niniejszym artykule wybrane wyniki badań są przykładem wielopłaszczyznowego podejścia do problemu pomiarów maszyn elektrycznych $\mathrm{w}$ warunkach przemysłowych. Standardowa aparatura pomiarowo-rejestrująca, która wykorzystywana jest $\mathrm{w}$ laboratoriach badawczych nie sprawdza się podczas pomiarów prowadzonych na obiektach pracujących w urządzeniach przemysłowych. W takich sytuacjach wymagana jest większa kreatywność w konfiguracji układów pomiarowych. Prowadzenie pomiarów długotrwałych często wymaga budowania własnych przyrządów np. rejestratorów, przedstawiono w artykule. Przydatność przedstawionych rozwiązań w praktyce inżynierskiej potwierdzają uzyskane wyniki. Obecnie autorzy pracuja nad wykorzystaniem telemetrycznego, wielokanałowego systemu akwizycji danych jako narzędzia do bezczujnikowej diagnostyki drganiowej maszyn elektrycznych wzbudzanych magnesami trwałymi [1-8]. Jest to nowa metoda diagnostyczna przeznaczona do nadzoru diagnostycznego dla generatorów i silników ze wzbudzeniem od magnesów trwałych.
[2] Barański M., New vibration diagnostic method of PM generators and traction motors - detecting of vibrations caused by unbalance. IEEEXplore, Energycon, 2014

[3] Barański M., Jarek T., Electrical machine with permanent magnets as a vibration sensor - a test stand model. IEEEXplore, ICEM, 2014

[4] Barański M., Będkowski B., Analysis of PMSM Vibrations Based on Back-EMF Measurements. IEEEXplore, ICEM, 2014

[5] Nandi S., Toliyat H.A, Condition monitoring and fault diagnosis of electrical machines-a review. Industry Applications Conference, 1999, pp.197-204

[6] Torregrossa D., Multiphysics Finite-Element Modeling for Vibration and Acoustic Analysis of Permanent Magnet Synchronous Machine. IEEE Transactions On Energy Conversion, 2011, pp 490500.

[7] Islam R., Analytical Model for Predicting Noise and Vibration in Permanent-Magnet Synchronous Motors. IEEE Transactions On Industry Applications, 2010, pp. 2346-2354.

[8] Lakshmikanth S., Natraj K.R., Rekha K.R., Noise and Vibration Reduction in Permanent Magnet Synchronous Motors - A Review. International Journal of Electrical and Computer Engineering, 2012, p.405.

[9] Georgakopoulos I.P., Mitronikas E.D., Safacas A.N., Detection of Induction Motor Faults in Inverter Drives Using Inverter Input Current Analysis. Industrial Electronics, IEEE Transactions on ,2011, Page(s): 4365 - 4373

[10] Bellini A., Filippetti F., Tassoni C., Capolino, G.A., Advances in Diagnostic Techniques for Induction Machines. Industrial Electronics, IEEE Transactions on , 2008, Page(s): 4109-4126

[11] Nemec M., Drobnic K., Nedeljkovic D., Fiser R., Ambrozic V., Detection of Broken Bars in Induction Motor Through the Analysis of Supply Voltage Modulation. Industrial Electronics, IEEE Transactions on, 2010, Page(s): 2879-2888

[12] Loparo K.A., Adams M.L., Wei Lin, Abdel-Magied M.F., Afshari N., Fault detection and diagnosis of rotating machinery. Industrial Electronics, IEEE Transactions on , 2000, Page(s): 1005 - 1014

[13] Zapaśnik R. Silniki indukcyjne z miedzianq odlewanq klatka wirnika, Maszyny Elektryczne: Zeszyty Problemowe, 71/2005.

[14] Strycharz J., O możliwości wczesnego wykrywania pęknięć prętów klatki wirnika podczas pracy maszyny asynchronicznej, Maszyny Elektryczne: Zeszyty Problemowe, 71/2005

[15] Bernatt M, Rut R., Mróz J., Ouszkodzeniach klatek wirnika, Maszyny Elektryczne: Zeszyty Problemowe, 79/2008

[16] Barański M., Decner A., Jarek T., Polak A., Diagnostyka i monitoring trakcyjnych maszyn elektrycznych przy wykorzystaniu autonomicznego, telemetrycznego, wielokanatowego systemu akwizycji danych, Logistyka 3/2015 